Article

\title{
Implementation of a Nutrition Program Reduced Post-Discharge Growth Restriction in Thai Very Low Birth Weight Preterm Infants
}

\author{
Suchada Japakasetr ${ }^{1}$, Chutima Sirikulchayanonta ${ }^{2, *}$, Umaporn Suthutvoravut ${ }^{3}$, \\ Busba Chindavijak ${ }^{4}$, Masaharu Kagawa ${ }^{5}$ and Somjai Nokdee ${ }^{6}$ \\ 1 Department of Nutrition, Faculty of Public Health, Mahidol University, Bangkok 10400, Thailand; \\ scdj01@yahoo.com \\ 2 College of Medicine, Rangsit University, Bangkok 10400, Thailand \\ 3 Department of Pediatrics, Faculty of Medicine, Ramathibodi Hospital, Mahidol University, \\ Bangkok 10400, Thailand; u_suthut@yahoo.com \\ 4 Department of Pharmacy, Faculty of Pharmacy, Mahidol University, Bangkok 10400, Thailand; \\ pybcd@mahidol.ac.th \\ 5 Institute of Nutrition Sciences, Kagawa Nutrition University, Saitama Prefecture 350-0288, Japan; \\ mskagawa@eiyo.ac.jp \\ 6 Nursing Department, Buddhasothorn Hospital, Chachoengsao 24000, Thailand; somjainokdee@gmail.com \\ * Correspondence: chutimabk@yahoo.com; Tel.: +66-2-354-4725
}

Received: 24 September 2016; Accepted: 8 December 2016; Published: 17 December 2016

\begin{abstract}
Very low birth weight (VLBW) preterm infants are vulnerable to growth restriction after discharge due to cumulative protein and energy deficits during their hospital stay and early post-discharge period. The current study evaluated the effectiveness of the preterm infant, post-discharge nutrition (PIN) program to reduce post-discharge growth restriction in Thai VLBW preterm infants. A prospective, non-randomized interventional cohort study was undertaken to assess the growth of 22 VLBW preterm infants who received the PIN program and compared them with 22 VLBW preterm infants who received conventional nutrition services. Infant's growth was recorded monthly until the infants reached six months' corrected age (6-moCA). Intervention infants had significantly greater body weights $(p=0.013)$ and head circumferences $(p=0.009)$. Also, a greater proportion of the intervention group recovered their weight to the standard weight at 4-moCA $(p=0.027)$ and at 6 -moCA $(p=0.007)$ and their head circumference to the standard head circumference at 6-moCA $(p=0.004)$ compared to their historical comparison counterparts. Enlistment in the PIN program thus resulted in significantly reduced post-discharge growth restriction in VLBW preterm infants. Further research on longer term effects of the program on infant's growth and development is warranted.
\end{abstract}

Keywords: very low birth weight preterm infant; growth restriction; post-discharge; nutrition program

\section{Introduction}

Very low birth weight (VLBW) preterm infants are those born before 37 weeks gestation weighing less than $1500 \mathrm{~g}$, and they comprise between $4 \%$ and $8 \%$ of neonatal live-births [1,2]. Survival of these small infants has significantly improved mainly due to the advancement of medical intervention in neonatal intensive care units (NICU) [2,3]. However, the extra-uterine growth restriction (EUGR), defined as a decrease in $z$-score greater than two standard deviations (SD) between birth to discharge [4], is common in the preterm population [5]. A recent cohort study estimated that a prevalence of being small for gestational age (SGA) among VLBW infants (birth weight 750-1500 g) born between 2005 and 2012 to be $44.4 \%-58.8 \%$ at discharge [6]. This may be caused by several health problems such 
as need for respiratory support, unstable glucose levels, early sepsis, risk of necrotizing enterocolitis and feeding intolerance during NICU stay. These concerns impact highly on the prescribed feeding regimen and result in unrecovered early protein and energy deficits accumulated during hospital admission [7]. Moreover, post-discharge growth restriction also usually occurs in these infants at $28 \%-40 \%$ until $18-22$ months corrected age (moCA) [8]. These poor postnatal growths are potentially associated with developmental delay [8], obesity and related complications, such as cardiovascular disease, type II diabetes mellitus and hypertension during adulthood [4,8,9].

In order to compensate for these nutritional deficits and improve the EUGR, the initiation of aggressive parenteral nutrition (PN) in the first week of life and fortified human milk (HM) to this population has been suggested during their hospital stay [10-12]. Furthermore, enriching HM or formula is widely recommended to decrease post-discharge growth restriction and accelerate catch-up growth $[10,13]$. However, the HM feeding rate in preterm infants usually declines after discharge [14]. Enriched-nutrient formula (EF) is therefore supplemented to provide adequate intakes of energy and nutrients to meet the infant's needs [15-17].

In 2012, a preliminary study was performed at Buddhasothorn Hospital, Chachoengsao, Thailand. It investigated the nutritional care services and growth outcomes in 85 VLBW preterm infants at pre- and post-discharge. The findings revealed that the HM feeding rate was decreased from $87 \%$ at discharge to 7\% at 6-moCA. After discharge, these infants received unfortified $\mathrm{HM}$ and/or standard term formula (TF). Moreover, $85 \%$ of VLBW preterm infants were below the standard growth at discharge and $43 \%$ remained as below the standard growth at 6 -moCA.

In order to reduce post-discharge growth restriction in this population, the preterm infant, post-discharge nutrition (PIN) program was developed and implemented at Buddhasothorn hospital in early 2014. Based on recent recommendations [10,15,18], it focuses on providing an EF in addition to fortified HM with regular monitoring after discharge to ensure infant nutritional intakes. The aim of the present study was to compare growth outcomes in VLBW preterm infants who enlist in the PIN program with those who received conventional nutrition services.

\section{Materials and Methods}

A prospective non-randomized interventional cohort study was conducted at Buddhasothorn Hospital, located in Chachoengsao province, Thailand. The present study was approved by the Institutional Review Boards of the Faculty of Public Health, Mahidol University (COA. No. MUPH 2014-002), Buddhasothorn Hospital (COA. No.EC-CA 007/2556) and Chachoengsao provincial health office (COA. No. PH_CCO_REC 003/56). The current study used the subgroup of the study that registered as a clinical trial with the Thai clinical trials registration number of TCTR20160211001.

\subsection{Participants}

A total of 22 VLBW preterm infants who were admitted and discharged from the NICU between March 2014 and February 2015 and given the PIN program were invited to participate in the current study. Detailed verbal and written explanations were given to parents of VLBW preterm infants and informed written consent was obtained from the parents of each participant. These infants were compared with records of 22 VLBW preterm infants who were born and discharged from the NICU between January 2012 and December 2013. The intervention group was enlisted in the PIN program after discharge to 6-moCA whereas; the comparison group received a conventional nutrition service at post-discharge for the same period of time.

A sample size of 22 preterm infants for each group was determined based on a previous study using a power of $80 \%$ and a significance level of $5 \%$ to detect a program effect of an increase of $5 \%$ on the body weight with favorable outcomes at 6-moCA [19]. Inclusion criteria of the study include: (1) birth at $\leq 34$ weeks gestation; (2) birth weight ranged between 750 and 1499 g; (3) no use of any medical feeding tube at discharge; and (4) residence in Chachoengsao. On the other hand, infants were excluded if they had: (1) severe respiratory problems; (2) serious congenital anomalies; (3) more than or 
equal to grade III periventricular or intraventricular hemorrhage; (4) surgical necrotizing enterocolitis; (5) gastrointestinal perforation; (6) severe retinopathy of prematurity; (7) severe birth asphyxia [6,19]; and also if (8) the mothers cannot communicate with researchers.

\subsection{Recruitment Process of the Participants}

Figure 1 describes the recruitment process of 22 VLBW preterm infants for both intervention and comparison group. The infants born in the comparison period were randomly assigned to the historical comparison group, stratified for sex and birth weight.

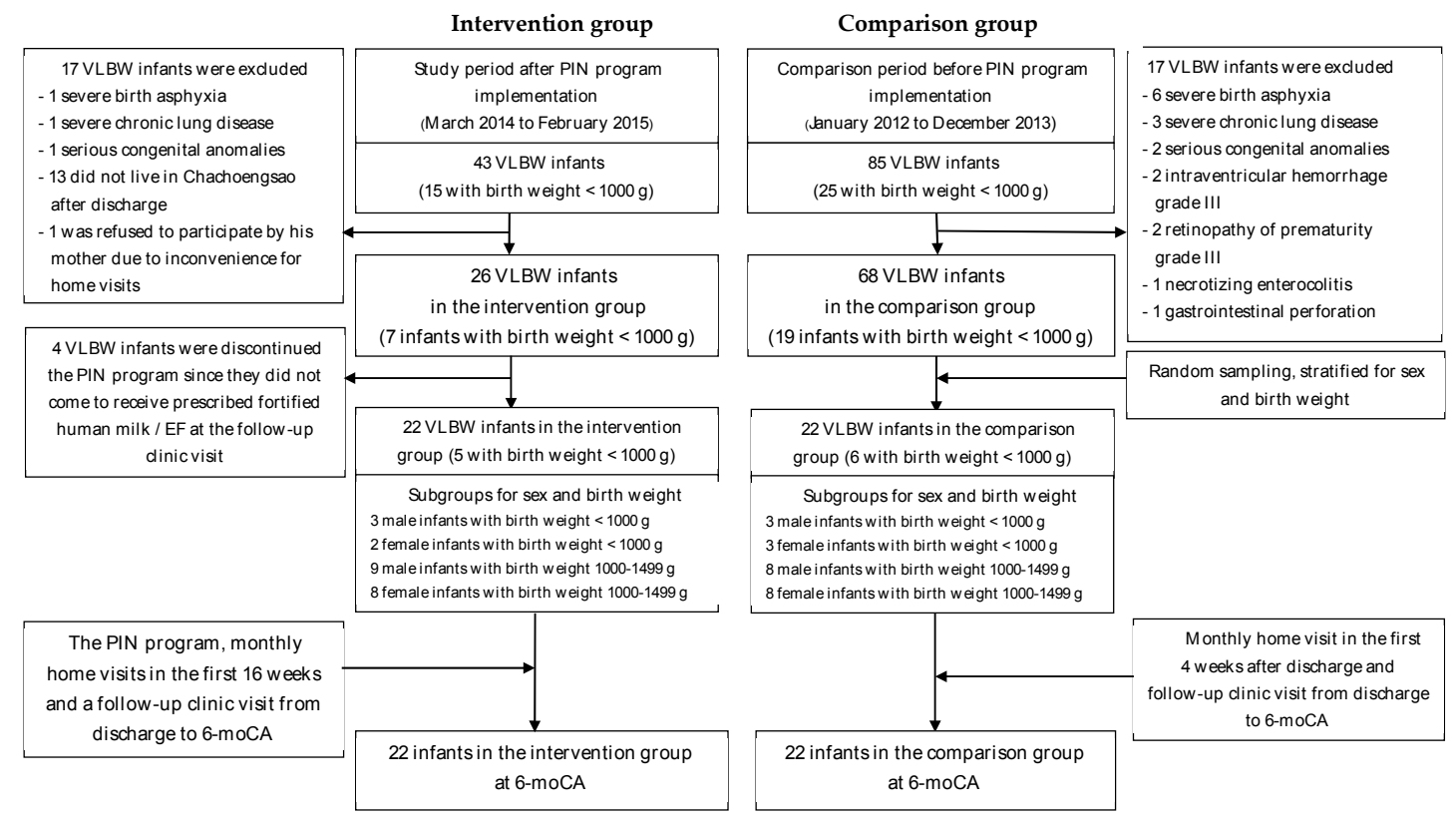

Figure 1. Recruitment process of participants. VLBW = very low birth weight, PIN = preterm infant post-discharge nutrition, $\mathrm{EF}=$ enriched-nutrient formula, $\mathrm{g}=\mathrm{gram}, \mathrm{moCA}=$ months corrected age.

\subsection{Nutritional Strategies Conducted for Both Groups during Hospital Admission}

Until their discharge from hospital, both groups received parenteral and enteral nutrition. Infants in both groups received individualized PN formulation in the first few weeks of life. When the infant's clinical status was improved, trophic oral feeding was introduced until the full feedings of at least 120-150 mL/kg/day were achieved [20]. All preterm infants mainly received their mother's own milk. Mothers were instructed by NICU nurses to assess volume intake of breast milk by test-weighing procedure [21] before discharge. In order to increase energy density from 20 to 24 or $27 \mathrm{kcal} / \mathrm{oz}$ during NICU stay as recommended by recent studies [22-24], infants were given fortified HM that was prepared by adding preterm formula (PF) into expressed HM (calculated by definite formula) once their volume of feeding reached $100 \mathrm{~mL} / \mathrm{kg} /$ day $[20,25]$.

\subsection{The PIN Program Conducted for the Intervention Group}

The PIN program is a post-discharge nutritional plan of feeding fortified HM and/or EF for VLBW preterm infants from discharge to 6-moCA. It is based on a commentary by the European Society for Pediatric Gastroenterology, Hepatology, and Nutrition (ESPGHAN) committee on nutrition [22] and a nutrition care practice guideline developed by the Oregon Pediatric Nutrition Practice Group (OPNPG) [15]. The program was developed based on outcomes from focused group discussions of a multi-disciplinary team in the hospital. Four experts-including two pediatricians, one neonatologist, and one nurse-reviewed and approved the program. It was implemented as a routine nutritional service at Buddhasothorn hospital since January 2014. The program also includes education on mothers 
prior to their discharge such as benefits of breastfeeding to preterm infants [26], essential knowledge for lactating mothers $[27,28]$, preparation method of fortified HM, feeding practices [29,30], and personal hygiene for their infant care after hospital discharge [29,30]. The contents of the education program were based on previous studies that recommended the importance of these variables [31,32].

\subsubsection{Enriched Milk Intake}

The fortified HM suggested in the program was prepared by adding a given calibrated spoon $(0.42 \mathrm{~g}$, contains $2.1 \mathrm{kcal})$ of a powdered preterm formula (PF) (Pre-Nan Abott, Bangkok, Thailand) per $\mathrm{oz}(30 \mathrm{cc})$ of expressed HM to prepare milk with energy density of $22 \mathrm{kcal} / \mathrm{oz}$. All intervention infants received fortified $\mathrm{HM}$ at discharge. If its volume was less than $50 \%$ of daily total volume intake, EF (Enfalac catch up care, Mead Johnson, Bangkok, Thailand) was supplemented to meet the infant needs with a goal of energy including $85-120 \mathrm{kcal} / \mathrm{kg} /$ day and $1.5-2.5 \mathrm{~g} / \mathrm{kg} /$ day of protein according to their corrected age $[10,15,22]$.

Specific written instructions on the fortification of HM and reconstitution of EF powder as well as containers for the preparation and storage of reconstituted milk were provided to each parent. In addition, the written instructions were repeated verbally and parental understanding was confirmed by research personnel. Dietary intake records were given to parents at discharge to assess actual milk and complementary food intake of infants. At the follow-up clinic, the mothers or caregivers were asked for more detailed information of their records. Volume of fortified expressed HM, EF, and other fluid intakes were determined by measuring in oz according to the label on the milk bottle.

\subsubsection{Introduction of Semi-Solid Foods}

The introduction of semi-solid foods was commenced if: (1) they reached 4-6 months after birth; (2) body weight was not less than $5 \mathrm{~kg}$; (3) they had no extrusion reflex; (4) they had well controlled neck and chair sitting posture; (5) they developed an ability to receive spoon feeding; and (6) they developed an ability to show desire or refusal of food [33-36]. Type and formula of semi-solid foods recommended in the PIN program was based on guidelines of complementary foods for Thai infant and toddlers by Thai Ministry of Public Health [36]. In the PIN program, Thai foods such as a pulp of Thai rice, pumpkin, egg yolk, some kinds of Thai vegetable, such as Coccinia grandis (dtam-leung) were recommended to the infants from 6 to 9 months after birth. In addition, half a teaspoon of vegetable oil per $250 \mathrm{~g}$ of semisolid foods was added to prevent fat soluble vitamin deficiencies [36].

\subsubsection{Biochemical Blood Tests and Nutrient Supplementation}

Biochemical blood profiles were also assessed monthly as a high-risk follow-up clinic. One $\mathrm{mL}$ of blood sample was taken at blood drawing unit from all infants and hematocrit (Hct), calcium (Ca), phosphorus (P), alkaline phosphatase (ALP), and blood urea nitrogen (BUN) were examined in order to monitor iron deficiency anemia [37], bone health [38], and nutritional status, including sufficiency of protein. All analyses were conducted at the laboratory unit in the hospital. However, the historical group did not conduct a regular biochemical blood tests after discharge at the follow-up clinic visit. As a result, with an exception of Hct, a nutritional status of historical group was unable to be compared with the intervention group during 1- to 6-moCA and therefore did not include in the results of the current study. Moreover, monthly home visits were performed to monitor HM fortification procedure and infant feeding practices [19].

All infants received $2 \mathrm{mg} / \mathrm{kg} /$ day of iron at discharge. When abnormal levels of biochemical markers were identified, special nutrient supplementations were prescribed by a pediatrician at a follow-up clinic as these follows:

- Hct < 35\%: Increase dose of ferrous sulfate/fumarate solution from 2 to $4-5 \mathrm{mg} / \mathrm{kg} /$ day $[17,37]$.

- Total Ca < 8.0 mg/dL: Supplement calcium suspension 100-140 mg/kg/day [15,17] 
- Phosphorus < $5.5 \mathrm{mg} /$ day and/or ALP > $450 \mathrm{IU} / \mathrm{L}$ : Supplement phosphate solution $60-90 \mathrm{mg} / \mathrm{kg} /$ day $[15,17]$

- $\quad$ BUN $>20 \mathrm{mg} / \mathrm{dL}$ : Consider substitution with unfortified HM and/or standard term formula (TF) [10].

The infants also received $0.5 \mathrm{~mL} /$ day of multivitamin drop (MVD) (1 mL of MVD—composed of 2000 international unit (IU) of vitamin A, 400 IU of vitamin D and other water soluble vitamins) - until infants received total daily milk intake of $>32 \mathrm{oz}(1000 \mathrm{~mL})$ [15]. However, non-fortified HM and/or TF was substituted when infants cannot tolerate with fortified $\mathrm{HM}$ and/or EF, or had an excessive rate of weight gain, and also showed Ca, P, and BUN above their normal levels [10].

Estimated volume of breastfeeding was derived by test weighing procedure [21]. Energy and selected nutrients intakes (protein, vitamin A and D, calcium, phosphorus, zinc, and iron), at 2-, 4-, and 6-moCA were estimated using HM composition values from literatures $[39,40]$ manufacturer label claims for PF, EF and TF, drug label of MVD and ferrous fumarate drop, commercial complementary feeding formula and complementary foods composition recommended by the Thai Ministry of Public Health [36].

A nutritionist explained to the mothers/caregiver about the procedure of recording actual amount of all milk feeding, complementary food intake, and nutrient supplementation before infant discharge and also re-checked their practices monthly at the follow-up clinic visit. These records were kept by mothers/caregivers at home and by a nutritionist during home visit and at a follow-up clinic visit.

\subsection{The Conventional Nutrition Services Conducted for the Comparison Group}

Prior to their infant discharge, parents in the comparison group received general education such as latching technique and observations of feeding intolerance without specific nutritional education. After discharge, infants received unfortified HM and/or TF. They were provided with $2-5 \mathrm{mg} / \mathrm{kg} /$ day of ferrous fumarate solution and $0.5-1 \mathrm{~mL} /$ day of MVD according to a decision of the in-charge pediatrician at a follow-up clinic. Hematocrit was also tested for all infants at every clinic visits; while the other chemical blood tests, including $\mathrm{Ca}, \mathrm{P}, \mathrm{ALP}$ and BUN were performed at some visits according to pediatricians' decisions.

Enteral intake data of the comparison group was also obtained from dietary intake recorded by mothers/caregivers and nutritional records by a nutritionist at a follow-up clinic as performed in the intervention group. Differences of the nutritional activities between the groups are described in Table 1.

Table 1. Comparisons of activities in the preterm infant post-discharge nutrition (PIN) program and conventional nutrition services.

\begin{tabular}{ll}
\hline \multicolumn{1}{c}{ The PIN Program Activities } & \multicolumn{1}{c}{ Conventional Nutrition Activities } \\
\hline $\begin{array}{l}\text { Giving formal nutritional education to } \\
\text { parents/caregivers }\end{array}$ & $\begin{array}{l}\text { I. Pre-discharge activities } \\
\text { parents/caregivers }\end{array}$ \\
\hline \multicolumn{1}{c}{ II. Post-discharge activities } \\
\hline $\begin{array}{l}\text { Giving enriched-nutrient HM and/or EF to the } \\
\text { infants from discharge to 6-moCA }\end{array}$ & $\begin{array}{l}\text { Giving unfortified HM and /or TF from discharge to } \\
\text { infant weaning }\end{array}$ \\
\hline $\begin{array}{l}\text { Using revised biochemical blood tests and } \\
\text { nutrition supplements protocol }\end{array}$ & $\begin{array}{l}\text { Using biochemical blood tests according to decisions } \\
\text { by in-charge pediatricians }\end{array}$ \\
\hline $\begin{array}{l}\text { Using revised criteria to start and recommended } \\
\text { types of semi-solid foods to preterm infants }\end{array}$ & $\begin{array}{l}\text { Suggestions mainly about time to start semi-solid } \\
\text { foods at six months after birth without other specific } \\
\text { criteria to start semi-solid foods }\end{array}$ \\
\hline $\begin{array}{l}\text { Monthly home visit until preterm infants } \\
\text { reached 6-moCA }\end{array}$ & Home visit only one time after hospital discharge \\
\hline moCA = months corrected age; HM = human milk $\cdot$ EF = enriched-nutrient formula; TF = term formula.
\end{tabular}

moCA = months corrected age; $\mathrm{HM}$ = human milk; $\mathrm{EF}$ = enriched-nutrient formula; $\mathrm{TF}$ = term formula. 


\subsection{Differences in Milk Formula between the Groups}

The energy and nutrients values of fortified HM and EF used in the intervention group and unfortified HM $[39,40]$ and TF used in the comparison group are shown in Table 2. Brands of TF formula were derived from nutritional records at a follow-up clinic in the historical group. Composition of TF is obtained from the average amount of ingredients from four commercial brands of TF in Thailand (S-26, Dumex Hi-Q, Lactogen and Enfalac $\mathrm{A}^{+}$) which contains equal energy density and protein per $100 \mathrm{~mL}$, but are slightly different for the remaining nutrients.

The energy density of fortified HM and reconstituted formula of EF is 21.8 and $22.5 \mathrm{kcal} / \mathrm{oz}$; while those of unfortified HM and TF is 19.7 and $20.1 \mathrm{kcal} / \mathrm{oz}$, respectively. Fortified HM contains higher protein than unfortified $\mathrm{HM}$ and TF by $12.5 \%$ and $22.5 \%$, respectively, but the remaining nutrients are equal to or less than TF. EF also contains higher protein, calcium, phosphorus, vitamin D and zinc by $42.9 \%, 79.2 \%, 70.6 \%, 33.8 \%$, and $20.0 \%$, respectively, and $>100 \%$ of vitamin A and iron compared to those in TF.

Table 2. Composition of energy and selected nutrients in fortified human milk (HM) and enriched-nutrient formula (EF) in the intervention group versus unfortified HM and term formula (TF) in the comparison group.

\begin{tabular}{ccccc}
\hline \multirow{2}{*}{ Composition } & \multicolumn{2}{c}{ Intervention Group } & \multicolumn{2}{c}{ Comparison Group } \\
\cline { 2 - 5 } & Fortified HM & EF & Unfortified HM & TF \\
\hline Energy (kcal) & 72.60 & 75.00 & 65.60 & 67.00 \\
Protein (g) & 1.80 & 2.10 & 1.60 & 1.47 \\
Vitamin A (IU) & 122.40 & 343.30 & 72.00 & 160.83 \\
Vitamin D (IU) & 20.50 & 63.00 & 12.00 & 47.07 \\
Calcium (mg) & 38.03 & 82.00 & 29.00 & 45.77 \\
Phosphorus (mg) & 19.03 & 48.00 & 14.00 & 28.13 \\
Zinc (mg) & 0.63 & 0.72 & 0.53 & 0.60 \\
Iron (mg) & 0.25 & 1.37 & 0.13 & 0.63
\end{tabular}

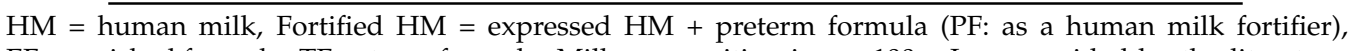
$\mathrm{EF}=$ enriched formula, $\mathrm{TF}=$ term formula, Milk composition is per $100 \mathrm{~mL}$ as provided by the literature and manufacturer, EF and TF were available cow milk protein-based formula.

The differences of feeding type and nutrient supplementation between the groups are summarized in Table 3.

Table 3. Comparisons of feeding type and nutrient supplementations for preterm infants after discharge between the intervention and comparison group.

\begin{tabular}{|c|c|c|}
\hline & Intervention Group & Comparison Group \\
\hline $\begin{array}{l}\text { I. Feeding type } \\
\text { 1.1 Milk intake at discharge } \\
\text { to 6-moCA }\end{array}$ & $\begin{array}{l}\text { Fortified HM and/or EF with energy } \\
\text { density of } 22 \mathrm{kcal} / \mathrm{oz}\end{array}$ & $\begin{array}{l}\text { Unfortified HM and/or TF with } \\
\text { energy density of } 20 \mathrm{kcal} / \mathrm{oz}\end{array}$ \\
\hline 1.2 Semi-solid foods & $\begin{array}{l}\text { Recommended formula based on } \\
\text { complementary food guideline for infants } \\
\text { and toddlers by Thai MOPH }\end{array}$ & $\begin{array}{l}\text { Commercial formula and/or any } \\
\text { formula based on caregivers' decision }\end{array}$ \\
\hline \multicolumn{3}{|l|}{$\begin{array}{l}\text { II. Nutrient supplementations } \\
\text { 2.1 At discharge }\end{array}$} \\
\hline Iron & $\begin{array}{l}2 \mathrm{mg} / \mathrm{kg} / \text { day, increase to } 4-5 \mathrm{mg} / \mathrm{kg} / \text { day } \\
\text { if Hct }<35 \%\end{array}$ & $2-5 \mathrm{mg} / \mathrm{kg} /$ day * \\
\hline MVD & $\begin{array}{l}0.5 \mathrm{~mL} / \text { day until infants had total daily } \\
\text { milk intake of }>32 \mathrm{oz}\end{array}$ & $0.5-1 \mathrm{~mL} / \mathrm{kg} /$ day * \\
\hline Calcium suspension & $100-140 \mathrm{mg} / \mathrm{kg} /$ day if total $\mathrm{Ca}<8.0 \mathrm{mg} / \mathrm{dL}$ & 90-120 mg/kg/day* \\
\hline Phosphate solution & $\begin{array}{l}60-90 \mathrm{mg} / \mathrm{kg} / \text { day if } \mathrm{P}<5.5 \mathrm{mg} / \text { day } \\
\text { and } / \text { or ALP }>450 \mathrm{IU} / \mathrm{L}\end{array}$ & $60-90 \mathrm{mg} / \mathrm{kg} /$ day * \\
\hline
\end{tabular}

* refers to dose of nutrient supplementation based on pediatricians' decisions, $\mathrm{HM}=$ human milk, $\mathrm{EF}=\mathrm{enriched}$ formula, $\mathrm{TF}=$ term formula, moCA = months corrected age, $\mathrm{MOPH}=$ Ministry of Public Health, Hct = hematocrit, $\mathrm{MVD}=$ multivitamin drop, $\mathrm{Ca}=$ calcium, $\mathrm{dL}=$ deciliter, $\mathrm{P}=$ phosphorus, $\mathrm{ALP}=$ alkaline phosphatase. 


\subsection{Growth Assessments Conducted with Both Groups}

Body weight, length and head circumference of infants in both groups were measured monthly, using revised anthropometric protocol for newborn by the same staff at the follow-up clinic. The hospital staff who perform growth measurement was trained and validated their measuring techniques every three months by the supervisor who is an expert in infant growth measurement. A digital balance (MS 2400; two decimals, maximum load $20 \mathrm{~kg}$, maximum length measured $80 \mathrm{~cm}$ ) was used for both weight and length measurements and a tape measure (Hochestmass $1.9 \times 150 \mathrm{~mm}$ ) was used for a head circumference measurement.

All data of the infants in the comparison group were recorded from patient charts during hospitalization and out-patient profiles at a follow-up clinic as secondary data until infants reached 6-moCA. Infant growth status was assessed by the Fenton [41] and WHO growth charts [42,43].

\subsection{Statistical Analysis}

Differences in energy and nutrient intakes between the groups were assessed by the Mann-Whitney $U$ test. Comparisons of anthropometric variables between the two groups from 1- to 6-moCA were examined using multivariate of covariance (MANOVA) repeated measures. Mixed model analysis was used to adjust multiple measurements of each infant. The categorical data were compared using chi-squared test. Data analyses were conducted using PASW SPSS statistics (version 18.0, SPSS Inc., Chicago, IL, USA). All statistical analyses were examined with a significance level of 0.05 .

\section{Results}

\subsection{Baseline Characteristics of the Participants}

Descriptive characteristics of infants were shown in Table 4. There were no statistically significant differences in baseline characteristics between the groups.

Table 4. Baseline characteristics of the intervention and comparison group.

\begin{tabular}{|c|c|c|c|}
\hline Variables & $\begin{array}{c}\text { Intervention Group } \\
\quad(n=22)\end{array}$ & $\begin{array}{l}\text { Comparison Group } \\
(n=22)\end{array}$ & $p$-Value \\
\hline Sex, $n(\%)$ & Male, 13 (59.0) & Male, $11(50.0)$ & 0.763 \\
\hline GA at birth, week \pm day & $29 \pm 12$ day & $30 \pm 14$ day & 0.501 \\
\hline Twin, $n(\%)$ & $3(13.6)$ & $6(27.3)$ & 0.457 \\
\hline \multicolumn{4}{|l|}{ Growth status at birth } \\
\hline Birth weight, $\mathrm{g}$ & $1192 \pm 202$ & $1151 \pm 208$ & 0.502 \\
\hline Length, $\mathrm{cm}$ & $39.1 \pm 2.6$ & $38.4 \pm 3.7$ & 0.525 \\
\hline Head circumference, $\mathrm{cm}$ & $26.1 \pm 1.8$ & $26.4 \pm 1.9$ & 0.626 \\
\hline \multicolumn{4}{|l|}{ SGA at birth } \\
\hline Body weight, $n(\%)$ & $1(4.5)$ & $2(9.1)$ & 1.000 \\
\hline Length, $n(\%)$ & $1(4.5)$ & $1(4.5)$ & 1.000 \\
\hline Head circumference, $n(\%)$ & $2(9.1)$ & $2(9.1)$ & 1.000 \\
\hline \multicolumn{4}{|l|}{ SGA at discharge } \\
\hline Body weight, $n(\%)$ & $19(86.4)$ & $20(90.9)$ & 1.000 \\
\hline Length, $n(\%)$ & $10(45.5)$ & $14(63.6)$ & 0.364 \\
\hline Head circumference, $n(\%)$ & $15(68.2)$ & $12(54.5)$ & 0.453 \\
\hline PMA at discharge, week \pm day & $37 \pm 12$ day & $38 \pm 20$ day & 0.199 \\
\hline LOS, days & $52 \pm 12$ & $53 \pm 17$ & 0.895 \\
\hline \multicolumn{4}{|l|}{ Feeding type at discharge, $n(\%)$} \\
\hline Breast milk feeding & $18(81.8)$ & $17(77.3)$ & 1.000 \\
\hline Mixed feeding & $3(13.6)$ & $4(18.2)$ & 1.000 \\
\hline Standard formula & $1(4.5)$ & $2(9.1)$ & 1.000 \\
\hline \multicolumn{4}{|l|}{ Growth status at term (40 weeks) } \\
\hline Body weight, $\mathrm{g}$ & $2631 \pm 538$ & $2426 \pm 531$ & 0.145 \\
\hline Length, $\mathrm{cm}$ & $47.7 \pm 2.7$ & $46.9 \pm 2.9$ & 0.318 \\
\hline Head circumference, $\mathrm{cm}$ & $33.1 \pm 1.6$ & $32.2 \pm 2.3$ & 0.470 \\
\hline Maternal age (years) & $22.5 \pm 4.8$ & $25.3 \pm 5.5$ & 0.087 \\
\hline
\end{tabular}

$n=$ number of infant; GA = gestational Age; SGA = small of gestational age; PMA = postmenstrual age; LOS = length of hospital stay. Data are expressed as mean $\pm \mathrm{SD}$. The differences between the groups were determined by chi-squared test. 


\subsection{Human Milk Feeding and Introduction of Semi-Solid Foods}

The volume of HM consumed ( $\mathrm{mL} / \mathrm{kg} /$ day) and proportion of HM volume per total volume of all milk feeds per day (\%) among infants in the intervention group was greater than those of the comparison group $(p<0.05)$ at 6 -moCA, but not 2-and 4-moCA. However, the total duration of HM feeding did not differ significantly between two groups. The length of time from birth to the introduction of semi-solids was also not significantly different (Table 5).

Table 5. Comparisons of exclusively human milk feeding, feeding duration and a timing of introducing semisolid foods between the groups.

\begin{tabular}{|c|c|c|c|}
\hline & $\begin{array}{c}\text { Intervention Group } \\
(n=22) \\
\text { Median (Q1-Q3) }\end{array}$ & $\begin{array}{c}\text { Comparison Group } \\
(n=22) \\
\text { Median (Q1-Q3) }\end{array}$ & $p$-Value \\
\hline \multicolumn{4}{|l|}{ Exclusively of HM feeding } \\
\hline $\mathrm{HM}$ intake, $\mathrm{mL} / \mathrm{kg} /$ day & $40.37(5.51-111.14)$ & $61.20(3.05-139.55)$ & 0.234 \\
\hline Proportion of HM volume per & $35.50(10.17-79.17)$ & $48.50(20.21-120.21)$ & 0.381 \\
\hline \multicolumn{4}{|l|}{ Total volume of milk feeds per day, $\%$} \\
\hline \multicolumn{4}{|l|}{4 -moCA } \\
\hline $\mathrm{HM}$ intake, $\mathrm{mL} / \mathrm{kg} /$ day & $24.67(13.34-61.55)$ & $27.45(10.00-57.80)$ & 0.761 \\
\hline Proportion of HM volume per & $22.82(15.09-61.09)$ & $21.86(16.33-56.33)$ & 0.859 \\
\hline \multicolumn{4}{|l|}{ Total volume of milk feeds per day, $\%$} \\
\hline \multicolumn{4}{|l|}{ 6-moCA } \\
\hline $\mathrm{HM}$ intake, $\mathrm{mL} / \mathrm{kg} /$ day & $11.73(3.16-13.51)$ & $3.05(1.12-11.43)$ & $0.044 *$ \\
\hline Proportion of HM volume per & $11.82(4.43-16.43)$ & $2.27(0.56-7.94)$ & $0.041 *$ \\
\hline \multicolumn{4}{|l|}{ Total volume of milk feeds per day, $\%$} \\
\hline Total HM feeding duration, weeks after birth & $16.00(10.00-26.00)$ & $18.00(12.00-24.00)$ & 0.427 \\
\hline $\begin{array}{l}\text { Time at introduction of semisolid foods, } \\
\text { weeks after birth }\end{array}$ & $20.00(17.00-23.00)$ & $21.00(19.00-24.00)$ & 0.625 \\
\hline
\end{tabular}

$n=$ number of infant, $\mathrm{Q} 1=$ the first quartile, $\mathrm{Q} 3=$ the third quartile, $\mathrm{HM}=$ human milk. moCA $=$ months corrected age. Total HM feeding duration refers to duration of exclusively HM feeding and/or mixed feeding (HM feedings plus formula feedings). Differences between groups were assessed by Mann-Whitney $U$ test.

* refers to statistically significant differences.

\subsection{Nutritional Intake}

Table 6 shows differences in daily energy and nutrient intakes of both groups. The intervention group showed greater energy and nutrient intakes except in zinc and iron compared to the comparison group at 2-, 4- and 6-moCA. It was also found that a median iron intake in both groups were slightly greater than the daily recommendation for healthy term infants.

Table 6. Comparisons of daily energy and nutrient intakes of preterm infants between the groups.

\begin{tabular}{|c|c|c|c|c|}
\hline Energy/Nutrient & $\begin{array}{l}\text { Intervention Group } \\
\qquad(n=22) \\
\text { Median (Q1-Q3) }\end{array}$ & $\begin{array}{c}\text { Comparison Group } \\
(n=22) \\
\text { Median (Q1-Q3) }\end{array}$ & $p$-Value & RDA \\
\hline \multicolumn{5}{|l|}{ Energy, kcal/kg } \\
\hline 2-moCA & 91.08 (89.27-93.46) & 88.40 (85.85-91.74) & 0.014 & $85-120$ \\
\hline 4-moCA & 86.39 (82.15-88.22) & 76.67 (72.65-78.16) & 0.001 & \\
\hline 6-moCA & 82.07 (80.11-88.63) & $69.22(66.49-71.98)$ & $<0.001$ & \\
\hline \multicolumn{5}{|l|}{ Protein, g/kg } \\
\hline 2-moCA & $2.87(2.44-3.30)$ & 2.21 (1.95-2.69) & 0.024 & $1.5-2.5$ \\
\hline 4-moCA & $2.48(2.01-2.89)$ & 2.07 (1.73-2.17) & 0.037 & \\
\hline 6-moCA & $1.85(1.67-2.25)$ & 1.53 (1.39-1.63) & $<0.001$ & \\
\hline \multicolumn{5}{|l|}{ Vitamin A, IU/kg } \\
\hline 2-moCA & $555.66(294.81-779.81)$ & $219.66(165.33-357.06)$ & 0.004 & $320-700$ \\
\hline 4-moCA & $476.99(301.20-665.91)$ & 209.63 (185.04-238.95) & $<0.001$ & \\
\hline 6-moCA & $389.03(227.10-521.58)$ & $202.24(191.11-221.02)$ & 0.035 & \\
\hline \multicolumn{5}{|l|}{ Vitamin D, IU/kg } \\
\hline 2-moCA & $107.98(45.14-145.78)$ & $50.00(36.09-71.00)$ & 0.007 & $60-160$ \\
\hline 4-moCA & 91.19 (55.00-125.30) & $42.72(32.06-47.84)$ & $<0.001$ & \\
\hline 6-moCA & $73.23(40.22-96.57)$ & $40.78(38.40-44.72)$ & $<0.001$ & \\
\hline
\end{tabular}


Table 6. Cont.

\begin{tabular}{|c|c|c|c|c|}
\hline Energy/Nutrient & $\begin{array}{l}\text { Intervention Group } \\
\qquad(n=22) \\
\text { Median (Q1-Q3) }\end{array}$ & $\begin{array}{c}\text { Comparison Group } \\
(n=22) \\
\text { Median (Q1-Q3) }\end{array}$ & $p$-Value & RDA \\
\hline \multicolumn{5}{|l|}{ Calcium, mg/kg } \\
\hline 2-moCA & 85.80 (63.95-88.95) & $68.24(63.17-69.86)$ & $<0.001$ & $60-120$ \\
\hline 4-moCA & $94.64(78.61-100.08)$ & $54.20(51.76-57.94)$ & $<0.001$ & \\
\hline 6-moCA & $66.01(49.04-69.60)$ & 48.75 (45.77-49.87) & 0.016 & \\
\hline \multicolumn{5}{|l|}{ Phosphorus, mg/kg } \\
\hline 2-moCA & $40.43(31.31-59.31)$ & $33.13(30.00-36.92)$ & $<0.001$ & $35-60$ \\
\hline 4-moCA & $71.31(66.32-77.83)$ & $32.29(30.14-34.73)$ & $<0.001$ & \\
\hline 6-moCA & $44.35(35.08-48.81)$ & $30.30(29.66-34.33)$ & 0.018 & \\
\hline \multicolumn{5}{|l|}{ Zinc, mg/kg } \\
\hline 2-moCA & $0.78(0.70-0.84)$ & $0.74(0.70-0.78)$ & 0.226 & $0.5-1$ \\
\hline 4-moCA & $0.72(0.64-0.79)$ & $0.710 .69-0.75)$ & 0.451 & \\
\hline 6-moCA & $0.67(0.59-0.72)$ & $0.64(0.59-0.69)$ & 0.572 & \\
\hline \multicolumn{5}{|l|}{ Iron, $\mathrm{mg} / \mathrm{kg}$} \\
\hline 2-moCA & $4.95(4.30-5.72)$ & $4.37(3.99-5.16)$ & 0.080 & $2-4$ \\
\hline 4-moCA & $5.02(3.64-5.47)$ & $5.30(4.16-5.49)$ & 0.411 & \\
\hline 6-moCA & $4.73(3.17-5.58)$ & $4.51(2.68-5.41)$ & 0.231 & \\
\hline
\end{tabular}

$\mathrm{Q} 1=$ the first quartile, $\mathrm{Q} 3=$ the third quartile, $\mathrm{PIs}=$ preterm infants, RDA = recommended dietary allowance, the upper limit is for PIs 37-40 weeks GA, the lower limit is for term infants at six months of age, no = number, moCA $=$ months corrected age, $\mathrm{IU}=$ international unit.

\subsection{Infant Growth Outcomes}

Compared to the comparison group, the intervention group showed significantly greater body weight $(p=0.013)$ at 4 - and 6-moCA and head circumference $(p=0.009)$ at 6-moCA (Figure 2). However, no significant difference in length and weight gain velocity were observed between two groups at any time point of age. Furthermore, a greater proportion of the intervention group reached body weight greater than $-2 \mathrm{SD}$ ( $Z$ score) at 4 -moCA ( $81.8 \%$ vs. $45.5 \%, p=0.027)$ and 6 -moCA $(90.9 \%$ vs. $50.0 \%$, $p=0.007)$ compared with their comparison counterpart. In addition, the intervention group reached head circumference greater than $-2 \mathrm{SD}$ ( $Z$ score) at $6-\mathrm{moCA}(95.5 \%$ vs. $54.5 \%, p=0.004)$ compared to the comparison group (Table 7). On the other hand, no differences were observed for length. Also, there was no over-standard growth or growth with higher +2SD ( $Z$ score) for body weight, length, and head circumference in both groups. Moreover, there was no correlation between HM feeding duration and any growth outcomes.

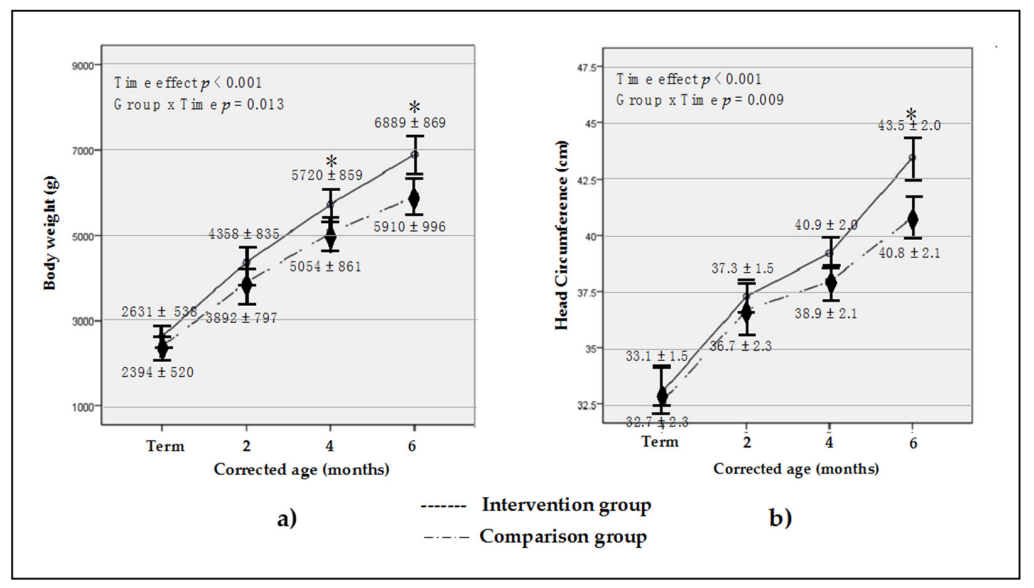

Figure 2. Anthropometric measurement of body weight, (a) and head circumference, (b) of the intervention and comparison group $(n=22)$. Data are reported as unadjusted mean $\pm \mathrm{SD}$. * denote a significant difference between groups at a specific time point with intervention greater than the comparison group (body weight at 4-moCA, $p=0.001$, and 6-moCA, $p<0.001$; head circumference at 6-moCA, $p<0.001)$. 
Table 7. Comparisons of growth status of preterm infants between the groups.

\begin{tabular}{|c|c|c|c|}
\hline \multirow[b]{2}{*}{ Growth Status } & \multicolumn{2}{|c|}{$n(\%)$} & \multirow[b]{2}{*}{$p$-Value } \\
\hline & $\begin{array}{l}\text { Intervention Group } \\
\qquad(n=22)\end{array}$ & $\begin{array}{c}\text { Comparison Group } \\
\qquad(n=22)\end{array}$ & \\
\hline \multicolumn{4}{|l|}{ 2-moCA, higher-2SD ( $Z$ score) in } \\
\hline Body weight & $14(63.6)$ & $9(40.9)$ & 0.227 \\
\hline Length & $15(68.2)$ & $8(36.4)$ & 0.069 \\
\hline Head circumference & $17(77.3)$ & $10(45.5)$ & 0.062 \\
\hline \multicolumn{4}{|l|}{ 4-moCA, higher-2SD ( $Z$ score) in } \\
\hline Body weight & $18(81.8)$ & $10(45.5)$ & $0.027 *$ \\
\hline Length, $n(\%)$ & $17(77.3)$ & $10(45.5)$ & 0.062 \\
\hline Head circumference, $n(\%)$ & $18(81.8)$ & $11(50.0)$ & 0.055 \\
\hline \multicolumn{4}{|l|}{ 6-moCA, higher-2SD ( $Z$ score) in } \\
\hline Body weight & $20(90.9)$ & $11(50.0)$ & $0.007 *$ \\
\hline Length & $17(77.3)$ & $11(50.0)$ & 0.116 \\
\hline Head circumference & $21(95.5)$ & $12(54.5)$ & 0.004 * \\
\hline
\end{tabular}

moCA $=$ months corrected age, $-2 \mathrm{SD}(Z$ score $)=-2 \mathrm{SD}$ line in $Z$ score growth chart for newborn by World Health Organization. Data are expressed as number of cases (percentage). The difference between intervention and comparison group was determined by chi-square test. * refers to statistical significance.

\section{Discussion}

The current study found an increase in the proportion of infants who were underweight (after adjustment for gestational age) in both groups; $4.5 \%$ at birth and $86.3 \%$ at discharge for the intervention group and $9.1 \%$ at birth and $86.9 \%$ at discharge for the comparison group. The results may indicate that early protein and energy deficits were not recovered during hospital admission regardless of the groups. Our findings were consistent with previous studies $[4,8,9,44,45]$ and the present study suggested a difficulty of preventing SGA among VLBW preterm infants during hospital admission.

The present study showed differences in anthropometric variables of fortified $\mathrm{HM}$ and/or EF fed versus HM alone and/or TF fed VLBW preterm infants from discharge to 6-moCA. The results indicated that the intervention group had significantly greater weight at 4- and 6-moCA and head circumference at 6-moCA compared to the comparison group. These results indicated the usefulness of the PIN program to compensate for energy and nutritional deficits which VLBW preterm infants experienced during their hospital stay and better recovery using fortified HM and/or EF. While there are controversies in beneficial effects of both fortified HM and enriched formula on growth parameters in preterm infants at post-discharge $[7,18,46]$, the results from the current study were consistent with other studies that observed better recovery in infants who received energy and nutrient-enriched HM or formula at early hospital discharge [47-50].

In addition, the results showed significant differences in a proportion of infants reaching standard weight at 4- and 6-moCA, and head circumference at 6-moCA while no difference was observed at 2-moCA. This result showed that the PIN program may be effective in shortening the period of post-discharge growth restriction by 4-moCA without rapid acute effects. Casey, et al. [45] reported that achieving optimal catch-up growth during a post-natal period, especially by six months after term, will significantly result in better neurodevelopmental outcomes from 18 months to 6 years compared with those who achieved catch-up growth later. Considering suggestion by Casey, et al. [45], the PIN program that provides adequate nutrition to preterm infants during such a critical period may have beneficial impact on both short- and long-term health in this particular population.

Consistently, the nutrient intakes of infants with fortified HM and EF during study period were greater and more consistent with current dietary recommendations $[15,23]$ than infants with unfortified $\mathrm{HM}$ and/or TF. These findings may attribute to the effect of enriching HM and formula to increase energy and protein intake. In addition, MVD, Ca, and P supplementation prescribed at a follow-up clinic according to the study protocol resulted in significantly higher intake of these nutrients. However, iron and zinc intakes did not differ between groups. This may be because of a similarity in iron and 
zinc supplementation practices in both groups. The results also showed a greater volume of human milk and the proportion of feed volume in the intervention group at 6-moCA. However, based on the obtained results, we interpreted the results as due to higher consumption of energy and protein that contained in enriched HM rather than increased volume.

While the PIN program included an education for mothers about benefits of breastfeeding before infant discharge, the present study did not show improvement in feeding duration between the groups and, in fact, was shorter than a previous study that reported a proportion and duration of exclusive HM feeding [20]. The results may indicate insufficient and inadequate lactation support of the PIN program to overcome problems that mothers experienced at post-discharge. Although the PIN program made more frequent home visits compared to the conventional service, the content including educational tools delivered prior to discharge and at each home visit should be adjusted as well as increasing involvement of lactation experts and frequencies of both on-site and distant counseling opportunities. In addition, the current study may indicate a presence of additional issues that prevent mothers from continuing HM feeding after discharge. As a result, further research may be warranted to evaluate factors that influence mothers to continue feeding HM to their child.

\section{Study Limitations}

Limitations of the current study included using the historical comparison group which contributed to slightly to differences in composition of TF formula intake. In addition, some data deviations might occur, such as an estimation of breast milk volume intake in some breastfed infants due to inadequate skill of test-weighing procedure in some mothers. Next, the currently applied inclusion and exclusion criteria also limited the extrapolation of the observations as documented in this cohort to all cases. Furthermore, except Hct, we cannot compare the nutritional status of biochemical blood test from 1- to 6-moCA. The main reason is that for the historical group, there were no regular biochemical blood tests after discharge at the follow-up clinic visit in the previous routine practice. The small sample size limits the interpretation and generalization of these results. Further studies are recommended in this area. Lastly, we use non-randomization to evaluate the program, resulting from a limitation of number of participants in a research setting.

\section{Conclusions}

Enlistment in a PIN program with enriched HM and formula feeding from hospital discharge to 6-moCA resulted in significantly reduced post-discharge growth restrictions for VLBW preterm babies compared to those who received unfortified HM and TF in conventional practices. Regular monitoring is needed to educate mothers or caregivers not to under- or overfeed their infants. Further lactation support and developed maternal education programs are needed to encourage continued HM feeding after discharge. Further studies are warranted with concurrent comparison groups and a longer follow-up period to analyze infant growth, neurodevelopment, and body composition.

Acknowledgments: We would like to thank the Director of Buddhasothorn Hospital for permission to conduct this study in the hospital and the NICU and hospital staff for coordination and assistance with providing the data. We also thank Dechavudh Nityasuddhi for attentive support and for his suggestions regarding statistical analysis. The study was partially funded by the Cerebos Health Research Foundation for Thai Society.

Author Contributions: S.J. was the principal investigator and carried out data collection. C.S. was responsible for overall supervision including the concept of the study, steps in the preterm infant nutrition program evaluation and data collection. S.J., C.S., U.S., B.C., M.K. and S.N. made contributions to the design of the study and the content validity of the nutrition program. U.S. invited and consulted with the experts on content validity of the protocol. S.N. provided substantial assistance with program implementation and research planning. J.S. was involved in the literature review and drafting of the manuscript. M.K. made contributions in coordination and program arrangements during S.J.'s Japan visit for conceptualization of the project proposal and assisted in editing the manuscript. C.S. revised the content and approved the final draft manuscript and all authors read and approved the final manuscript.

Conflicts of Interest: The authors declare no conflict of interest. 


\section{References}

1. Afjeh, S.A.; Sabzehei, M.K.; Fallahi, M.; Esmaili, F. Outcome of very low birth weight infants over three years report from an Iranian center. Iran. J. Pediatr. 2013, 23, 579-587. [PubMed]

2. Fanaroff, A.A.; Stoll, B.J.; Wright, L.L.; Carlo, W.A.; Ehrenkranz, R.A.; Starh, A.R.; Bauer, C.R.; Donovan, E.F.; Korones, S.B.; Laptook, A.R.; et al. Trend in neonatal morbidity and mortality of very low birth weight infants. Am. J. Obstet. Gynecol. 2007, 196, 147-148. [CrossRef] [PubMed]

3. Ruegger, C.; Hegglin, M.; Adams, M.; The Swiss Neonatal Network. Population based trends in mortality, morbidity and treatment for very preterm and very low birthweight infants over 12 years. BMC Pediatr. 2012, 12. [CrossRef] [PubMed]

4. $\quad$ Euser, A.M.; de Wit, C.C.; Finken, M.J.; Rijken, M.; Wit, J.M. Growth of preterm born children. Horm. Res. Paediatr. 2008, 70, 319-328. [CrossRef] [PubMed]

5. De Curtis, M.; Rigo, J. Entrauterine growth restriction in very-low-birthweight infants. Acta Pediatr. 2004, 93, 1563-1568. [CrossRef]

6. Griffin, I.J.; Tancredi, D.J.; Bertino, E.; Lee, H.C.; Profit, J. Postnatal growth failure in very low birthweight infants born between 2005 and 2012. Arch. Dis. Child. Fetal Neonatal Ed. 2016, 101, F50-F55. [CrossRef] [PubMed]

7. McLeod, G.; Sherriff, J.; Patole, S. Post-discharge nutrition for high-risk preterm neonates. In Nutrition for the Preterm Neonate: A Clinical Perspective, 1st ed.; Patole, S., Ed.; Springer: Dordrecht, The Netherlands; Heidelberg, Germany; London, UK; New York, NY, USA, 2013; pp. 173-185.

8. Suppo, L.M.; Rugolo, S. Growth and developmental outcomes of the extremely preterm infant. J. Pediatr. 2005, 81, S101-S110.

9. Dusick, A.M.; Poindexter, B.B.; Ehrenkranz, R.A.; Lemons, J.A. Growth failure in the preterm infant: Can we catch up? Semin. Perinatol. 2003, 27, 302-310. [CrossRef]

10. Su, B.H. Optimizing nutrition in preterm infants. Pediatr. Neonatol. 2014, 55, 5-13. [CrossRef] [PubMed]

11. Morgan, C. Early amino acid administration in very preterm infants: Too little, too late or too much, too soon? Semin. Fetal Neonatal Med. 2013, 18, 160-165. [CrossRef] [PubMed]

12. Lee, B.S. Nutritional strategy of early amino acid administration in very low birth weight infants. Korean J. Pediatr. 2015, 58, 77-83. [CrossRef] [PubMed]

13. Yuen, D.E. Feeding premature infants after hospital discharge. Paediatr. Child Health 1998, 3, $307-308$. [PubMed]

14. Menezes, M.A.; Garcia, D.C.; de Melo, E.V.; Cipolotti, R. Preterm newborns at Kangaroo Mother Care: A cohort follow-up from birth to six months. Rev. Paul. Pediatr. 2014, 32, 171-177. [CrossRef] [PubMed]

15. Authority, O.H. Nutrition Practice Care Guidelines for Preterm Infants in the Community. Available online: http://public.health.oregon.gov/HealthPeopleFamilies/wic/Documents/preterm.pdf (accessed on 16 January 2014).

16. Adamkin, D.H. Nutritional Strategies for Very Low Birth Weight Infants; Cambridge University Press: New York, NY, USA, 2009; pp. 101-108.

17. Dall'Agnola, A.; Beghini, L. Post-discharge supplementation of vitamins and minerals for preterm neonates. Early Hum. Dev. 2009, 85, S27-S29. [CrossRef] [PubMed]

18. Teller, I.C.; Embleton, N.D.; Griffin, I.J.; van Elberg, R.M. Post-discharge formula feeding in preterm infants: A systematic review mapping evedence about role of micronutrient enrichment. Clin. Nutr. 2016, 35, 791-801. [CrossRef] [PubMed]

19. Aimone, A.; Rovet, J.; Ward, W.; Jereries, A.; Campbell, D.M.; Asztalos, E.; Feldman, M.; Vaughan, J.; Westall, C.; Whyte, H.; et al. Growth and body composition of human milk-fed premature infants provided with extra energy and nutrients early after hospital discharge: 1-year follow-up. J. Pediatr. Gastroenterol. Nutr. 2009, 49, 456-466. [CrossRef] [PubMed]

20. Ors, R. The practical aspects of enteral nutrition in preterm infants. J. Pediatr. Neonatal Individ. Med. 2013, 2, 35-40.

21. Arthur, P.G.; Hartmann, P.E.; Smith, M. Measurement of the milk intake of breast-fed infants. J. Pediatr. Gastroenterol. Nutr. 1987, 6, 758-763. [CrossRef] [PubMed] 
22. ESPGHAN Committee on Nutrition; Aggett, P.J.; Agostoni, C.; Axelsson, I.; De Curtis, M.; Goulet, O.; Hernell, O.; Koletzko, B.; Lafeber, H.N.; Michaelsen, K.F.; et al. Feeding preterm infants after hospital discharge. J. Pediatr. Gastroenterol. Nutr. 2006, 42, 596-603. [CrossRef] [PubMed]

23. Agostoni, C.; Buonocore, G.; Carnielli, V.P.; de Curtis, M.; Darmaun, D.; Decsi, T.; Domellof, M.; Embleton, N.D.; Fusch, C.; Genzel-Boroviczeny, O.; et al. Enteral nutrient supply for preterm infants: Commentary from the European Society of Paediatric Gastroenterology, Hepatology and Nutrition Committee on Nutrition. J. Pediatr. Gastroenterol. Nutr. 2010, 50, 85-91. [CrossRef] [PubMed]

24. Arslanoglu, S.; Bertino, E.; Coscia, A.; Tonetto, P.; Giuliani, F.; Moro, G.E. Update of adjustable fortification regimen for preterm infants: A new protocol. J. Biol. Regul. Homeost. Agents 2012, 26, 65-67. [PubMed]

25. Dutta, S.; Singh, B.; Chessell, L.; Wilson, J.; Janes, M.; McDonald, K.; Shahid, S.; Gardner, V.A.; Hjartarson, A.; Purcha, M.; et al. Guidelines for feeding very low birth weight infants. Nutrients 2015, 7, 423-442. [CrossRef] [PubMed]

26. Enrico, B.; Nicola, P.D.; Giuliani, F.; Peila, C.; Cester, E.; Vassia, C.; Pirra, A.; Tonetto, P.; Coscia, A. Benefits of human milk in preterm infant feeding. J. Pediatr. Neonatal Individ. Med. 2012, 1, 19-24.

27. Dewey, K.G. Energy and protein requirements during lactation. Annu. Rev. Nutr. 1997, 17, 19-36. [CrossRef] [PubMed]

28. Raiten, D.J.; Kalhan, S.C.; Hay, W.W., Jr. Maternal nutrition and optimal infant feeding practices: Executive summary. Am. J. Clin. Nutr. 2007, 85, S577-S583.

29. Turck, D. Safety Aspects in Preparation and Handling of Infant Food. Ann. Nutr. Metab. 2012, 60, $211-214$. [CrossRef] [PubMed]

30. Agostoni, C.; Axelsson, I.; Goulet, O.; Koletzko, B.; Michaelsen, K.F.; Puntis, J.W.; Rigo, J.; Shamir, R.; Szajewska, H.; Turck, D.; et al. Preparation and handling of powdered infant formula: A commentary by the ESPGHAN Committee on Nutrition. J. Pediatr. Gastroenterol. Nutr. 2004, 39, 320-322. [CrossRef] [PubMed]

31. Thakur, S.K.; Roy, S.K.; Paul, K.; Khanam, M.; Khatun, W.; Sarker, D. Effect of nutrition education on exclusive breastfeeding for nutritional outcome of low birth weight babies. Eur. J. Clin. Nutr. 2012, 66, 376-381. [CrossRef] [PubMed]

32. Benzies, K.M.; Magill-Evans, J.E.; Hayden, K.A.; Ballantyne, M. Key components of early intervention programs for preterm infants and their parents: A systematic review and meta-analysis. BMC Pregnancy Childbirth 2013, 13, S10. [CrossRef] [PubMed]

33. Fanaro, S.; Borsari, G.; Vigi, V. Complementary feeding practices in preterm Infants: An observational study in a Cohort of Italian infants. J. Pediatr. Gastroenterol. Nutr. 2007, 45, S210-S214. [CrossRef] [PubMed]

34. Krebs, N.F.; Hambidge, K.M. Complementary feeding: Clinically relevant factors affecting timing and composition. Am. J. Clin. Nutr. 2007, 85, S639-S645.

35. Sanchez-Carrillo, C.; Padilla, B.; Marin, M.; Rivera, M.; Cercenado, E.; Vigil, D.; Sanchez-Luna, M.; Bouza, E. Contaminated feeding bottles: The source of an outbreak of Pseudomonas aeruginosa infections in a neonatal intensive care unit. Am. J. Infect. Control 2009, 37, 150-154. [CrossRef] [PubMed]

36. Suthutvoravut, U.; Tuntrachewathorn, S.; Khunsanong, S. Manual of Complementary Feeding for Infants and Toddlers; Beyond Enterprise: Bangkok, Thailand, 2009; pp. 5-36.

37. Anemia of Prematurity. Available online: http://emedicine.medscape.com/article/978238 (accessed on 23 August 2015).

38. Abrams, S.A. Calcium and vitamin D requirements of enterally fed preterm infants. Pediatrics 2013, 131, e1676-e1683. [CrossRef] [PubMed]

39. Gidrewicz, D.A.; Fenton, T.R. A systematic review and meta-analysis of the nutrient content of preterm and term breast milk. BMC Pediatr. 2014, 14, 216. [CrossRef] [PubMed]

40. Boyce, C.; Watson, M.; Lazidis, G.; Reeve, S.; Dods, K.; Simmer, K.; McLeod, G. Preterm human milk composition: A systematic literature review. Br. J. Nutr. 2016, 116, 1033-1045. [CrossRef] [PubMed]

41. Fenton, T.R.; Kim, J.H. A systematic review and meta-analysis to revise the Fenton growth chart for preterm infants. BMC Pediatr. 2013, 13, 59. [CrossRef] [PubMed]

42. Rao, S.C.; Tompkins, J.; World Health Organization. Growth curves for preterm infants. Early Hum. Dev. 2007, 83, 643-651. [CrossRef] [PubMed]

43. Bhatia, J. Growth curves: How to best measure growth of the preterm infant. J. Pediatr. 2013, 162, S2-S6. [CrossRef] [PubMed] 
44. Cao, W.; Zhang, Y.H.; Zhao, D.Y.; Xia, H.P.; Zhu, T.W.; Xie, L.J. Risk factors for extrauterine growth restriction in preterm infants with gestational age less than 34 weeks. Zhongguo Dang Dai Er Ke Za Zhi 2015, 17, 453-458. [PubMed]

45. Casey, P.H. Growth of low birth weight preterm children. Semin. Perinatol. 2008, 32, 20-27. [CrossRef] [PubMed]

46. Young, L.; Embleton, N.D.; McCormick, F.M.; McGuire, W. Multinutrient fortification of human breast milk for preterm infants following hospital discharge. Cochrane Database Syst. Rev. 2013, 28, CD004866.

47. Young, L.; Morgan, J.; McCormick, F.M.; McGuire, W. Nutrient-enriched formula versus standard term formula for preterm infants following hospital discharge. Cocharne Database Syst. Rev. 2012, 14, CD004696.

48. Kuschel, C.A.; Harding, J.E. Multicomponent fortified human milk for promoting growth in preterm infants. Cochrane Database Syst. Rev. 2004, 1, CD000343.

49. Adamkin, D. Postdischarge nutritional therapy. J. Perinat. 2006, 26, S27-S30. [CrossRef] [PubMed]

50. Winston, W.K.; Koo, E.M.H. Posthospital discharge feeding for preterm infants: Effects of standard compared with enrinched milk formula on growth, bone mass and body composition. Am. J. Clin. Nutr. 2006, 84, 1357-1364.

(c) 2016 by the authors; licensee MDPI, Basel, Switzerland. This article is an open access article distributed under the terms and conditions of the Creative Commons Attribution (CC-BY) license (http://creativecommons.org/licenses/by/4.0/). 